\title{
Analytical Study of Undergraduate (BLS) \\ Department of Library Science, (University of Maiduguri, Nigeria between 2000 - 2006) \\ By
}

Katamba Abubakar Saka and Jibril Attahiru Alhassan

\begin{abstract}
Documentary source was used to provide analysis of the BLS projects submitted to Department of Library and Information Science, university of Maiduguri between 2000 and 2006. It was discovered that there was no single BLS project for the year 2001. A total of 355 BLS projects were submitted for the 6 years. In terms of study area $196(55.21 \%)$ projects were on North Eastern Nigeria. It was discovered that case study covers 176 $(49.88 \%)$ of the projects. The arrangement of the BLS projects by titles in ranked order showed that "problems, development and prospects in libraries" top the list with $46(12.96 \%)$ scores. Low scores were recorded for projects on Current Awareness Services (CAS), Library cooperation, library standard etc with each having 1 $(0.28 \%)$ project title.
\end{abstract}

\begin{abstract}
Department of Library Science University of Maiduguri

Department of Library Science University of Maiduguri was founded in December 1977 under the leadership of Dr. C.C Aguolu who was the pioneer Head of Department. The department, the fourth in the country was fully established in 1978 . It took off with 16 undergraduate students in 1978/79 session. The department introduced the Diploma in Library Science programme (DLS) was mounted and in 1982/83 academic session with 24 students. However the DLS programme is been phase out.
\end{abstract}

The library school presently runs the undergraduate programme and two postgraduate programmes (MLS and Ph.D). The Ph.D programme took off in 2006/2007 academic session. The department has 11 academic staff comprising of one professor, one reader, four senior lecturers; one lecturer I and two lecture II. The library school has departmental lecturer and a computer laboratory housed in the same building. (Bulletin: 2007)

\section{Review of Related Literature}

Goji (2007) compiled an annotated Bibliography of BLS projects submitted to the Department of Library and Information Science (University of Maiduguri) between 2000 and 2006. It contained t 310 entries. However, it did not provide a statistical analysis of the research work compiled. The present study was aimed at providing the descriptive analysis of the BLS projects for the 6 years.

Ndor (2004) wrote on Database of African Theses and Dissertation (DATAD) using university of Jos as a case study, lamented that the Hardware for the project include 2 computer, 1 scanner, 1 printer, 2 UPS. The software include procite 5; References Web, poster, xitami HTTP server; Omni page Pro
II to handle scanning abstracts; Corel word perfect 8/MS word and latest version of anti-virus.

A sample of University of Jos theses and dissertation bibliographic entries entry include Author (full name and email) gender, title, degree, supervisor(s), town and country, university and department, year of submission, Acronym (UNIJOS); abstract in alternative language; physical description, language of the these, availability and address; copyright statement, abstract; call number and key words. So far, University of Jos has converted 1,500 theses and dissertation into electronic format while additional 300 records have been completed.

A documentary work on "index to and characteristics of Articles published in the journal of library focus 1983 - 1999" was carried out by Ibrahim and Abubakar (2001). The researchers, not only indexed the journals but also provided analysis of the index entries by volume and year, by form of authorship, by location of contributing authors.

\section{Methodology}

Documentary sources and the accession register in the departmental library was consulted for the project. In order to obtain accurate data, a page by - page counting of the project list was made taken into consideration the year of submission, geographical distribution, key titles of the projects, and type of research adopted. Simple descriptive analysis involving frequency tables and percentages was adopted in the presentation of the result of the data analysed.

\section{Data Analysis and Discussion}

Based on data gathered as at 24th January 2008, the analysis is hereby provided into tables below: 
Table 1: Distribution of BLS Projects by Year of Submission.

\begin{tabular}{|c|c|c|}
\hline Year & Frequency & Percentage\% \\
\hline 2000 & 44 & 12.39 \\
\hline 2001 & - & - \\
\hline 2002 & 44 & 12.39 \\
\hline 2003 & 50 & 14.08 \\
\hline 2004 & 69 & 19.44 \\
\hline 2005 & 81 & 22.82 \\
\hline 2006 & 67 & 18.87 \\
\hline Total & 355 & 100 \\
\hline
\end{tabular}

From the above table, it was discovered that in 2001 there were no submission of BLS projects to the departmental library. It was discovered that no BLS student graduated in that particular year due to ASUU strike.

The available year records consulted showed that there were 355 BLS projects as at 24th January 2008. The year 2005 received the highest number of projects with $81(22.82 \%)$. This was followed by 2004 with $69(19.44 \%)$ projects. The least were recorded in 2000 and 2002 with 44 (12.39\%) BLS projects each.

Table 2:Geo-Political Zone spread of BLS projects.

\begin{tabular}{|l|c|c|}
\hline $\begin{array}{l}\text { Geo - political } \\
\text { zones/location }\end{array}$ & $\begin{array}{l}\text { Frequency or number } \\
\text { of BLS projects }\end{array}$ & $\%$ \\
\hline North East & 196 & 55.21 \\
\hline North West & 30 & 8.45 \\
\hline North Central & 42 & 11.83 \\
\hline $\begin{array}{l}\text { North East and } \\
\text { North West }\end{array}$ & 01 & $0-.28$ \\
\hline South South & 12 & 3.38 \\
\hline South East & 09 & 2.54 \\
\hline South West & 15 & 4.22 \\
\hline FCT Abuja & 37 & 3.66 \\
\hline Others & 355 & 10.42 \\
\hline \multicolumn{1}{|c|}{ Total } & & 100 \\
\hline
\end{tabular}

A careful assessment of the titles in relation to the project contents were made in order to identify the study areas in relation to the country's Geo political zones. The highest number of BLS project write -up were on North East zone with 196 $(55.21 \%)$ probably owing to the fact that the library school is situated in the North - East. This was followed by $42(11.83 \%)$ BLS projects from North Central zone. Majority of the 42 projects were on Jos town and Plateau state.
There were $37(10.42 \%)$ projects were on Bibliographies on Nigeria, Africa, HIV/AID, NNPC, Banks, and African Poetry etc. It was discovered that $1(0.28 \%)$ of the projects was on 2 Geo - political zones (North East and North West).

Table 3: Distribution of BLS projects by Research Method Adopted.

\begin{tabular}{|l|c|c|}
\hline $\begin{array}{c}\text { Research } \\
\text { methods }\end{array}$ & $\begin{array}{c}\text { Number of } \\
\text { BLS projects }\end{array}$ & $\%$ \\
\hline Experimental & - & - \\
\hline Survey & 92 & 25.92 \\
\hline Historical & 15 & 4.23 \\
\hline Evaluative & 34 & 9.58 \\
\hline Documentary & 38 & 10.70 \\
\hline Case study & 176 & 49.58 \\
\hline Total & 355 & 100 \\
\hline
\end{tabular}

A majority of the research method adopted was case study with $176(49.58 \%)$ projects; This was followed by survey method with 92 (25.92\%) projects.

Evaluative study attracted $34(9.58 \%)$ projects. The least was the Historical research having 15 (4.23\%) projects. None of the projects was on experimental study. 
Table 4: Ranked Order of BLS projects by Area of Study (2000 - 2006)

\begin{tabular}{|c|c|c|c|}
\hline $\begin{array}{l}\text { Rank Order } \\
\text { of Project } \\
\text { Titles }\end{array}$ & Titles of BLS projects $2000-2006$ & $\begin{array}{l}\text { Number of } \\
\text { BLS projects }\end{array}$ & $\begin{array}{l}\text { Percentage } \\
(\%)\end{array}$ \\
\hline 1 & $\begin{array}{l}\text { Problems, development and prospects of } \\
\text { libraries }\end{array}$ & 46 & 12.96 \\
\hline 2 & Bibliography & 39 & 10.99 \\
\hline 3 & Collection development & 32 & 9.01 \\
\hline 4. & Library services & 29 & 8.17 \\
\hline 5 & $\begin{array}{l}\text { Management/Administration of library } \\
\text { information centres }\end{array}$ & 24 & 6.76 \\
\hline 6 & Resources and services & 22 & 6.20 \\
\hline 7 & Information science & 21 & 5.92 \\
\hline 8 & Roles of libraries & 18 & 5.07 \\
\hline 9 & Technical services & 16 & 4.51 \\
\hline 10 & Information storage and retrieval system & 14 & 3.94 \\
\hline 11 & Preservation of library material & 12 & 3.38 \\
\hline 12 & Readers services & 12 & 3.38 \\
\hline 13 & $\begin{array}{l}\text { Library Automation/Automation/information } \\
\text { technology }\end{array}$ & 10 & 2.82 \\
\hline 14 & Theft and mutilation & 09 & 2.25 \\
\hline 15 & Book publishing and book trade & 08 & 2.25 \\
\hline 16 & Reading habits & 08 & 2.25 \\
\hline 17 & Users' attitude & 06 & 1.69 \\
\hline 18 & Professionalism & 04 & 1.13 \\
\hline 19 & Users education & 04 & 1.13 \\
\hline 20 & Library use pattern & 03 & 0.85 \\
\hline 21 & Containing education/training & 02 & 0.56 \\
\hline 22 & Academic achievement and library services & 01 & 0.28 \\
\hline 23 & Current awareness services (CAS) & 01 & 0.28 \\
\hline 24 & Library cooperation & 01 & 0.28 \\
\hline \multirow[t]{2}{*}{25} & Library standards & 01 & 0.28 \\
\hline & Total & 355 & 100 \\
\hline
\end{tabular}

The Key words in the project titles were determined in order to get the actual word/words that best explain the area of study. From the table above, 25 areas of study were determined within the 355 BLS projects for the 6 years $(2000-$ 2006). They were arranged in ranked order i.e from highest to the lowest. From the table, "problems, development and prospects of libraries" seem to be the dominant area of study with $46(12.96 \%)$. This means that the area has been exhaustively studied within the 6 years. Next to this was "Bibliographies" which have been compiled in the areas of HIV/AID, NNPC, African poetry, Bank, Nigerian constitution etc. Library services was ranked $4^{\text {th }}$ with $29(8.17 \%)$ projects which include public library services. The $5^{\text {th }}$ in the ranking order was the "Management/Administration of libraries and information centres" with $24(6.76 \%)$ project titles. This include funding, staffing, budgeting of libraries. The $6^{\text {th }}$ in the ranking order were resources and services which include book and non book materials and various library services such as circulation, technical and reference services.

The lowest and the least of the area of study were those of current awareness services, library cooperation, library standards, academic achievement and library service each with 1 $(0.28 \%)$ project areas of study respectively. The interesting thing in the above table was that the area of study with their corresponding number of project titles appeared in the order of magnitude i.e from highest to lowest.

It has however been discovered from the study that: 
1. There was no single BLS project in the year 2001 due to the ASUU strike.

2. The North East zone has the highest number of BLS projects in terms of the study area perhaps because of the location of the library school in the geopolitical zone.

3. Case study was the most frequently used research method while no single BLS project employed experimental method.

4. On the areas of study, "problems, development and prospects of libraries top the list with $46(12.96 \%)$ area of study while the remaining $291(77.04 \%)$ project were from other areas.

\section{Suggestions}

1. Accurate and up - to - date record of BLS projects submission should be kept especially in computer.

2. Undergraduate students be encourage to undertake research on national issues rather than only on regional aspects;

3. Students be made to diversify the scope of their researches to enable them employ other research method.

\section{References}

Aguolu, C.C. and Aguolu, I.E. (2002). Libraries and Information management in Nigeria. Maiduguri; Ed - Limform services P. 323.
In Ikem, J.E. (1984) "Pattern of 21 years of Bibliographic services and control, 1962 - 1982”. Nigerian Libraries, 32.

Goji, T.D. (2007). An Annotated Bibliography of Final year projects submitted to the Department of Library Science, University of Maiduguri (2000 - 2006). BLS Unpublished, Maiduguri 112p.

Ibrahim, U. and Abubakar, T. (2001). An Index to, and Characteristics of Articles Published in the Journal of Library Focus: 1983 - 1999. Library Focus vol.19, 2001, pp $58-65$.

Iwuji, H.O.M. (2005). Bibliographic control of Theses and Dissertation in Nigerian. In Markman, R and Waddel, M.L (1971).

Iwuji, H.O.M. (2005). Bibliographic control of Theses and Dissertations in Nigeria. Nigerian library and Information Science Trends. Vol. 3(1 and 2) 2005, pp 25 - 33.

Ndor, J.J. (2004). Database for African Theses and Dissertations DATAD: The university of Jos Experience. Borno Library, Archival and Information Science Journal Vol 3(1) 2004, pp $34-42$.

University of Maiduguri. Faculty of Education Bulletin. Nov - Dec. 2007 vol 5 (7) pp 7 and 10. 